\title{
Malignant Solitary Fibrous Tumor of the Parotid Gland
}

\author{
Dae Hwan Kim ${ }^{1}$, Ki Ju Cho ${ }^{1}$, Jin Pyeong Kim ${ }^{1}$, and Seung Hoon Woo ${ }^{1,2}$ \\ ${ }^{1}$ Departments of Otorhinolaryngology, ${ }^{2}$ Institute of Health Sciences, College of Medicine, Gyeongsang National University, Jinju, Korea
}

\section{이하선에서 발견된 악성 고립성 섬유종 1예}

김대환 ${ }^{1} \cdot$ 조기주 ${ }^{1} \cdot$ 김진평 $^{1} \cdot$ 우승훈 ${ }^{1,2}$

경상대학교 의과대학 이비인후과학교실, ${ }^{1}$ 건강과학원 ${ }^{2}$

\author{
Received June 14, 2016 \\ Revised August 2, 2016 \\ Accepted August 8, 2016 \\ Address for correspondence \\ Seung Hoon Woo, MD \\ Department of Otorhinolaryngology, \\ College of Medicine \\ Gyeongsang National University, \\ 79 Gangnam-ro, Jinju 52727, Korea \\ Tel $+82-55-750-8173$ \\ Fax $+82-55-759-0613$ \\ E-mail lesaby@hanmail.net
}

Solitary Fibrous tumor is usually arising in the pleura of the thoracic cavity and it has been described in a variety of extrapleural sites including the abdominal cavity, soft tissue, upper respiratory tract and rarely in head and neck region. We experienced a rare case of solitary fibrous tumor in the parotid gland. A 49-year-old woman presented with a painless mass in the left parotid. The mass was well-demarcated and easily dissected, and it showed a patternless arrangement of potential malignant spindle cells in a fibrotic background and prominent vascular structures. In immunochemistry, the mass cells were positive for CD34, vimentin, and negative for actin, S-100 protein, and cytokeratins. Therefore, the parotid mass diagnosed as SFT. During the 24 months of follow-up, there was no recurrence of tumor growth.

Korean J Otorhinolaryngol-Head Neck Surg 2017;60(10):522-6

Key Words Parotid gland $\cdot$ Salivary glands $\cdot$ Solitary fibrous tumor.
서 론

고립성 섬유종(solitary fibrous tumor)은 1931년 Klemperer 와 Coleman에 의해 처음 분류된 간엽세포 기원의 양성 방추 세포 종양으로 주로 흥막에서 발생하는 종양이다. ${ }^{1)}$ 간엽세포 종양으로 처음 분류된 이후, 양성중피종, 흥막섬유종, 장막밑 섬유종, 고립성 섬유종 등의 다양한 이름으로 불리었으나 조 직학적 특성, 발병위치, 조직학적 기원에 따라 고립성 섬유종 명칭이 통합되었다. ${ }^{2)}$ 최근 들어 흥막 외 여러 곳에서 발생한 예가 보고되고 있으나, ${ }^{3}$ 두경부에서는 드물게 발생한다고 알 려져 있다." 두경부에서는 주로 안와, 부비동, 구강에서 발생 한다고 알려져 있으며, 국내에서 비강 및 뒤통수에서 발생한 증례가 있으며 ${ }^{5,6)}$ 본 증례와 같은 이하선에 발생한 고립성 섬 유종은 매우 드문 것으로 알려져 있다.

고립성 섬유종은 피막으로 둘러싸여 있으며, 비전이성 병

This is an Open Access article distributed under the terms of the Creative Commons Attribution Non-Commercial License (http://creativecommons.org/licenses/by-nc/4.0) which permits unrestricted non-commercial use, distribution, and reproduction in any medium, provided the original work is properly cited.
변으로 알려져 있고, 대부분 특별한 증상 없는 양성 종양이지 만 드물게 악성의 가능성이 있는 종양으로 수술적으로 종양 의 완전 제거가 필요하다. ${ }^{7)}$ 조직학적으로 종양세포는 둥근 모양의 방추형태 세포가 불규칙하게 배열되어 있으며, 그 주 변으로 교원질이 둘러싸고 있는 양상을 보인다. 종양세포 주 위로 중간 크기의 혈관들이 많이 존재한다. 따라서 수술적 제거를 할 때, 항상 대량출혈의 가능성을 염두에 두어야 하 며, 필요시 혈관색전술을 고려해야 한다.

본 증례는 이하선에 발생한 고립성 섬유종으로, 처음 병원 내원했을 때는 특별한 증상 없이 만져지는 양성 경부 종물 이었지만, 시간이 지남에 따라 서서히 크기가 증가하여 안면 신경(facial nerve)마비를 일으킨 경우로, 이후 인접한 림프절 로 전이되고, 최종 조직검사 결과 악성종양으로 진단된 고립 성 섬유종 1 예를 문헌고찰과 함께 보고하고자 한다.

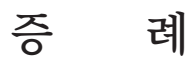

49세 여자 환자가 좌측 경부에 서서히 커지는 종물을 주 
소로 내원하였다. 과거력에서 3개월 전, 소뇌경색으로 우측 사지근력 약화소견 이외의 특이사항은 없었다. 신체검사에서 좌측 귀밑에서 약 $2 \mathrm{~cm}$ 크기의 통증은 없으며, 단단하고, 움 직이는 종물이 만져졌고, 그 밖에 부종이나 열감 등의 특이 증상은 없었다. 경부 전산화단층촬영에서 좌측 이하선 안에 경계가 명확하고 조영제 사용 시 강하게 조영 증강되는 3.3 $\mathrm{cm}$ 크기의 종물이 관찰되었으며, 주변에 조직 침범이나 변형 은 없었다(Fig. $1 \mathrm{~A}$ and B). 세침흡인 세포검사 결과 악성은 아니었으며, 양성의 세엽 세포 덩어리만 관찰되는 소견이었 다. 이하선 종양의 수술적 제거를 고려하였으나, 수술 전 시행 한 뇌혈관 자기공명검사에서 모야모야병이 진단되었다. 모야 모야병의 치료 및 경과관찰을 우선으로 하고 이하선 수술은 연기하여 경과관찰 하였으나, 얼마 되지 않아 경과관찰은 소 실되었다.

이후 2년 뒤, 다시 본원 이비인후과 외래 내원하였다. 2년 동 안, 좌측 경부종물에 대해 특별한 치료 및 경과관찰은 하지 않았다고 했으며, 최근 들어 다시 커지고 불편감이 지속되고 눈이 잘 안 감기면서 입이 안 움직이는 안면신경 마비 증상을 보여 타 병원에 내원하였고, 타 병원에서 종물 절제술을 시도 하였으나, 수술을 완료하지 못했다고 하였다. 환자의 상태는
종물을 절제하기 위한 절개선이 귀 앞에서 시작하여 경부까 지 이어진 상태였으나, 정확한 수술 부위에 대한 박리가 이루 어지지 않았고, 안면신경이 확인이 되지 않아 중간에 수술을 그만둔 상태였다. 이후 본원에서 추가로 시행한 전산화단층촬 영에서 이하선의 종물이 2년 전과 비교했을 때, 주변 조직 침 범이나 변형은 없었고, 조영제 사용 시 조영증강되는 종물이 똑같이 관찰되었으며 $3.3 \mathrm{~cm}$ 에서 $4.0 \mathrm{~cm}$ 으로 크기 증가하였 으며(Fig. $1 \mathrm{C}$ and D), 경부 림프절 level II 지역에 반응성 림 프절로 의심되는 림프절이 존재하였다. 그리고 입원 시 시행 한 안면신경 검사에서 이마를 들었을 때, 좌측이 약해져 있고, 눈을 감을 때 힘을 꽉 주어야 겨우 감을 수 있는 정도였으며, 입 운동이 좌측이 많이 약해져 있는 상태였고 House-Brackmann Grade III의 좌측 안면신경 마비 증상이 확인되었다. 따라서 악성화의 가능성을 염두에 두고 전신마취 하에 종물 을 포함하여 좌측 이하선절제술 및 림프절절제술을 시행하 였다.

수술 시 확인된 부분은 이전 수술 시 종물에 접근하는 박 리가 제대로 되지 않은 상태였고 이로 인한 심한 유착이 되어 있는 상태였다. 따라서 안면신경의 주가지(Main trunk)를 찾 아 종물을 제거하는 방법보다는 주변부에서 신경을 찾아 박
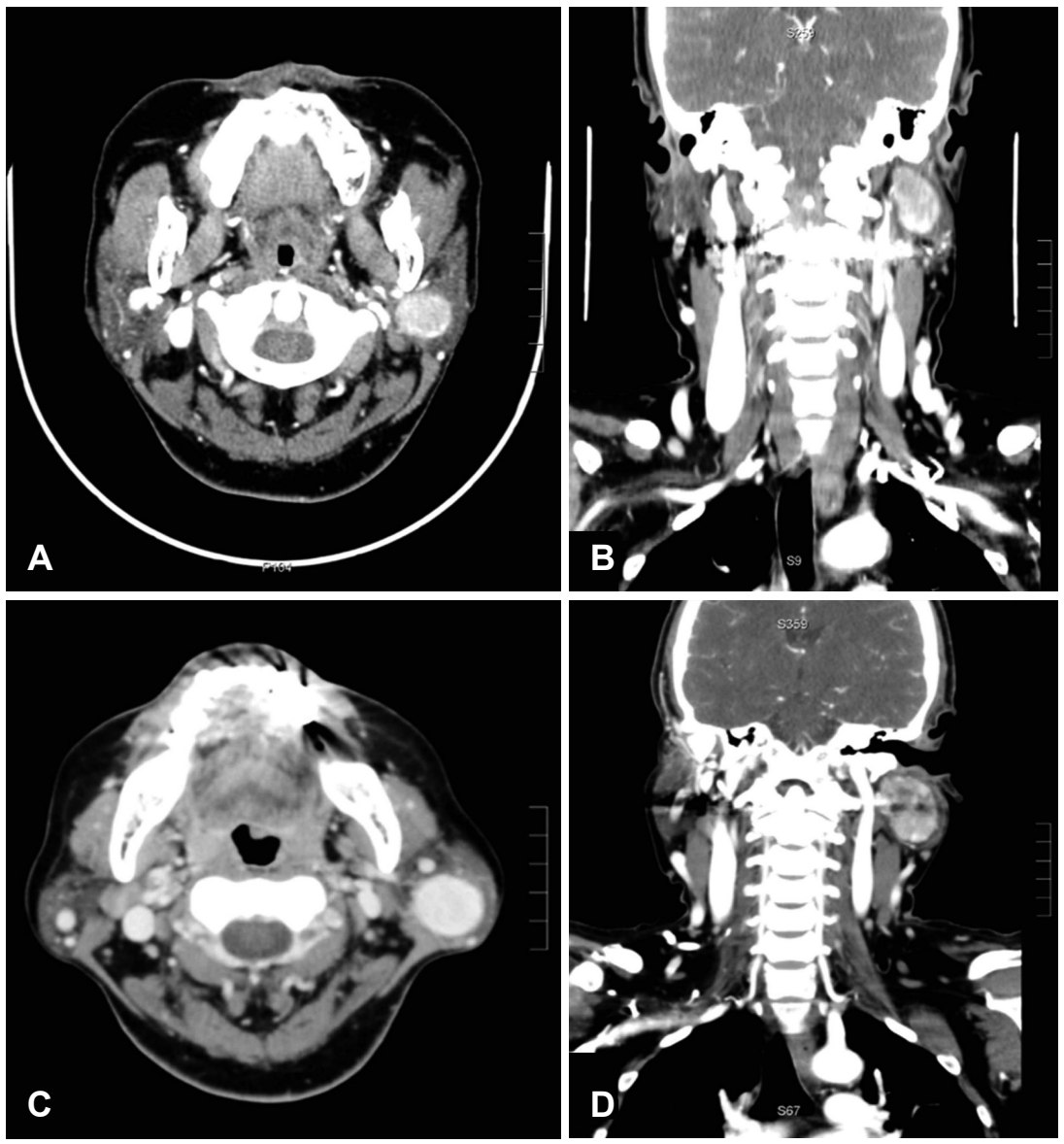

Fig. 1. First computed tomography images. The enhancing mass is located in the left parotid gland. Axial view (A). Coronal view. After 2 years, the mass size is increased (3.3 $\mathrm{cm} \rightarrow 4.0 \mathrm{~cm})(B)$. Axial view (C). Coronal view (D). 
리를 하고 종물을 제거하는 방법을 사용하였다. 안면신경의 볼가지(Buccal branch)로 추정되는 신경을 찾아 점차 중심부 를 향해 박리하였고(Fig. 2) 이후 이하선 심부에서 표면이 매 끄러운 $4 \times 2.5 \times 2 \mathrm{~cm}$ 크기의 회백색 종괴를 확인하고 제거 (Fig. 3)하였다. 전반적으로 안면신경 심부에서 발생한 종양이

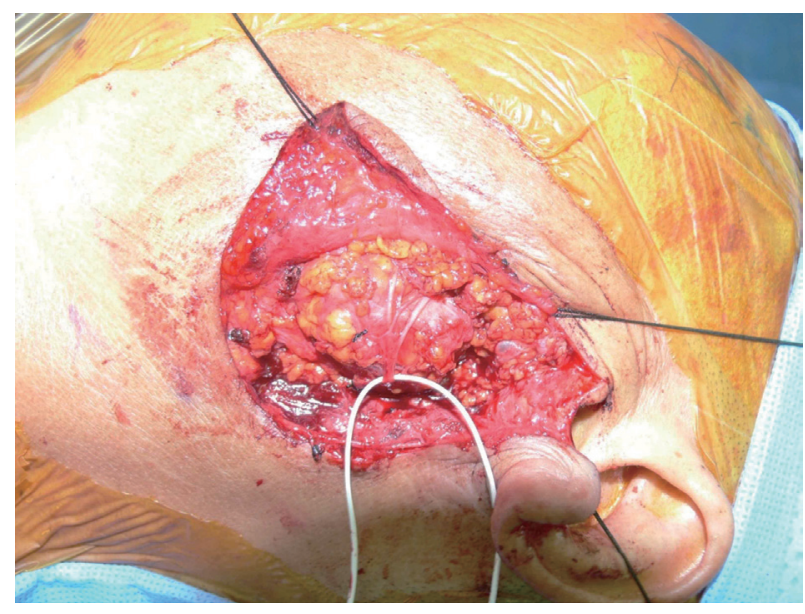

Fig. 2. Intraoperative view showing the nerve that estimated to buccal branch, and gradually dissect toward the main trunk of facial nerve.
안면신경을 밀고 있는 양상이었고 명확하게 신경을 침범한 흔적은 보이지 않았다. 동결절편 검사에서 악성의 가능성을 시사하여 이하선 하부의 임파선에 대해 좌측 Neck level II

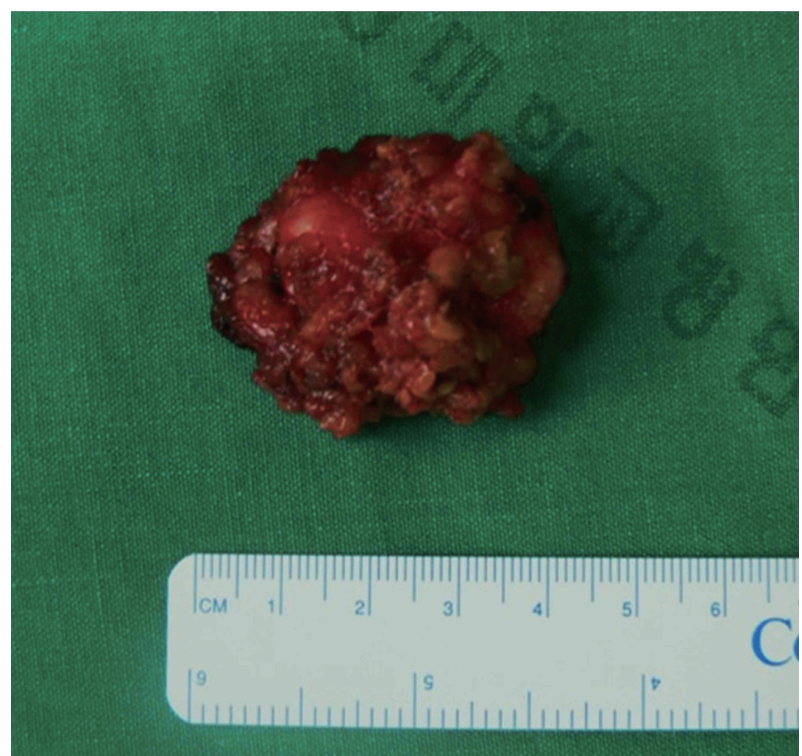

Fig. 3. Parotid mass was dissected. Macroscopic view shows a round shape tumor of firm and $4 \times 2.5 \times 2 \mathrm{~cm}$.
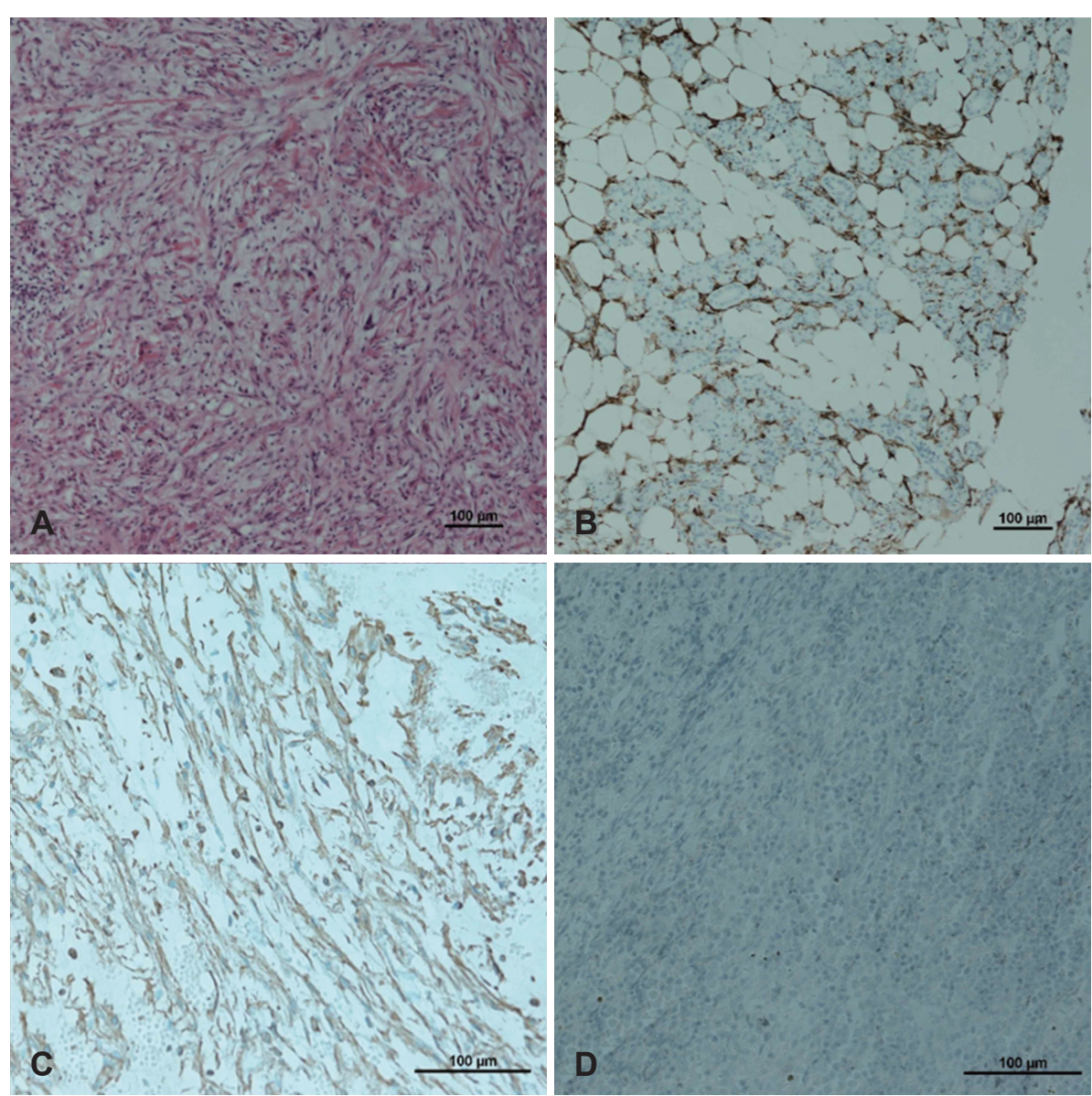

Fig. 4. Histopathological examination. Light microscopy, HematoxylinEosion staining (H\&E staining); the tumor showed the typical arranged bland spindle cells with variable cellularity and thick collagen bundles $(\times 100)(A)$. The most tumor cells stained for CD34 $(\times 100)(B)$. The tumor cells stained for vimentin $(\times 200)$ (C). The tumor cells are negative for p63 $(\times 200)(D)$. 
지역에 경부곽청술을 시행하였다.

병리조직검사(hematoxylin-eosion 염색)에서 방추세포가 풍부한 부분이 있었고, 세포가 적고 섬유성 기질로 채워진 부 분이 불규칙한 양상으로 관찰되었다(Fig. 4A). 면역조직화학 염색에서 CD34, vimentin에서 양성반응을 보였으며, cytokeratin, p63, anaplastic lymphoma kinase에서는 음성반응 을 보였다(Fig. 4B, C, and D). 이에 고립성 섬유종으로 진단 되었고, 같이 제거한 림프절에서도 CD34 염색에서 양성반응 을 보여 전이가 확인되었다. 수술 이후 원격전이 검사를 진행 하였고, 양전자방출단층촬영 및 골스캔에서 다른 원격전이 소견은 발견되지 않았다. 수술 후에도, 안면신경마비 증상은 호전되지 않았으며, 수술 부위 주변으로 방사선치료를 시행 하였다. 방사선치료 종료 후, 합병증 없이 퇴원하였다. 퇴원 후, 2년간 재발 없이 추적관찰 하고 있다.

\section{고 찰}

고립성 섬유종은 1767년, Lietaud에 의해 처음으로 기술되 었으며, 1870년 Wagner는 이 병의 고립된 특징에 대해 기술하 였다. 1931년, Klemperer와 Robin은 흥막종양을 광범위 중 피종 그리고 국소적 중피종 또는 고립성 섬유종, 두 가지 경 우로 분류하였다. ${ }^{1)}$ 이후, 중피 기원 종양에 대해 국소 섬유성 중피종, 국소 중피종, 고립성 섬유종 등의 이름이 제안되었다. 하지만, 이 종양이 간엽세포 기원임이 밝혀지면서, 고립성 섬 유종이란 이름으로 정리되게 되었다. 고립성 섬유종은 그 이 후로, 복강, 체간, 상기도, 두경부, 상하지 등에서도 보고되었 는데, 흉막 외 발생은 전체의 $30 \%$ 정도이며, 그 중에서 두경 부는 $6 \%$ 정도로 드물게 보고되고 있다. ${ }^{8)}$ 이중, 이하선에 발생 하는 경우는 매우 드물다. 고립성 섬유종은 경계가 분명하 고, 느리게 성장하며, 두경부의 경우, 발생위치에 따라 연하 곤란, 음성 변화, 저작장애, 수면무호흡, 비폐색 등 다양한 임 상증상을 발생시킨다. ${ }^{9}$ 본 증례에서는 이하선 내 고립성 섬유 종이 커짐에 따라 안면신경 마비 증상이 발생하였다.

일반적으로 고립성 섬유종은, 단단하며 명확한 경계를 보 이며, 부분적으로 소엽상의 부드럽고 흰 표면을 보이는 종물 이다. 흥막 외 고립성 섬유종의 크기는 중간값으로 $5 \sim 8 \mathrm{~cm}$ 정도이며, 반면에 이하선의 종양은 1 12 cm로 편차가 크며, 평균 크기는 $4.5 \mathrm{~cm}$ 이다. ${ }^{10)}$ 고립성 섬유종은 대부분 양성이 지만, 악성의 경우도 종종 보고 되고 있다. 흥막에서 발생한 고 립성 섬유종은 5 20\%에서 악성의 특징을 보였으며, 흉막 이 외의 위치에서는 악성의 경우는 드물다. ${ }^{11)}$ 고립성 섬유종 주변 림프절에 전이소견과 함께 악성으로 진단된 경우는 매우 드문 증례이다.
고립성 섬유종의 영상의학적 특성은 일반적으로 명확한 경계를 보이는 원형의 소엽상의 종물로 나타난다. ${ }^{12)}$ 전산화단 층촬영 영상에서는 저음영의 종물로 보이며, 조영증강된 전 산화단층촬영에서는 불균일하게 조영증강 되는 특징을 보인 다. 자기공명영상에서, T1-강조영상에서는 명확한 경계를 보 이는 종물이 근육과 동등신호강도로 보이거나 저신호강도로 나타난다. T2-강조영상, 특히 가돌리늄 조영증강 영상에서 는 저신호강도 및 고신호강도로 나타나며, 불규칙한 배열을 보이며, 비균질적으로 조영증강 되어 나타난다. ${ }^{13)}$

고립성 섬유종은 조직학적 특징으로 주로 진단한다. 특징 적인 방추세포와 교원질이 불규칙하게 배열된 부분이 있으 며, 주변조직과 경계가 명확하게 나누어져 있다. ${ }^{7)}$ 종양세포는 다발의 나선형, 혹은 섬유육종 같은 방식으로 배열되어 있 고, 그 주위로 수많은 중간 크기의 혈관들이 가지를 내며 많 이 존재한다. 혈관벽은 두껍고 유리질로 구성되어 있다. 종양 세포는 둥근 모양이며, 방추형태로 이루어져 있다. 종양세포 의 중심에 위치한 핵은 둥글거나 타원형이며, 세포질 물질의 유사세포함유물이 핵 내부에서 관찰된다. 그 외, 간질-점액 성 변화, 비만세포와 같은 염증세포와 같은 수많은 특징들이 보고되고 있다. 여러 이하선의 고립성 섬유종은 부분적으로 정상 침샘의 세엽과 관의 끝에 엮여 있다는 것으로 알려져 있다. ${ }^{14)}$

악성화를 나타낸 조직소견으로 Chan은 높은 세포밀도, 세포의 다형태성, 유사분열 수의 증가(>4 mitoses/10 high power field)를 제시했고, ${ }^{2}$ 이와 더불어 침윤성 경계, 출혈, 괴사 등의 조직소견도 악성과 관련이 있는 것으로 알려져 있 다. ${ }^{3)}$ 그 외 임상적으로는 종물의 크기가 클 때, 발병기간이 길 때, 종양을 불완전절제 했을 때, 악성의 가능성이 높다." 면역화학적검사도 진단에 도움을 준다. 고립성 섬유종의 대 부분의 경우에서는 특징적으로 CD34 항원의 강한 양성반응 을 보인다. 다른 항원으로는 $\mathrm{Bcl}-2$, neuron-specific enolase, smooth muscle actin, desmin 등에서 일부 양성반응을 보 이기도 한다. Desmin, cytokeratin, S-100 protein, HMB-45 에서는 음성반응 혹은 약양성 반응을 보인다. 일반적으로 세 침흡인검사를 기본으로 하는 고립성 섬유종의 진단, 그 중에 서도 특히 이하선에서 발생한 고립성 섬유종의 진단은 다음 과 같은 특징을 가진다. 세포도말검사에서 과세포성을 보이 고, 모세혈관, 핵 내부의 세포질 물질의 유사세포함유물 등 의 특징을 기본으로, 방추세포 종양을 통해서 진단할 수 있 다. 고립성 섬유종의 림프절 전이에 대한 증례는 신장에서 생 긴 고립성 섬유종이 장골림프절로 전이된 1 개의 증례 ${ }^{15)}$ 및 일부만 보고 되고 있으며, 이하선에서 발생한 고립성 섬유종 의 림프절 전이와 안면신경마비의 증례는 아직 보고된 바가 
없다.

조혈전구세포항원인 $\mathrm{CD} 34$ 는 주로 조혈줄기세포, 소혈관의 내피세포, 배아섬유아세포에서 주로 발현된다. 대부분의 암종, 흑색종, 림프종에서는 CD34 항원이 음성으로 나타난다. 하지 만 anti-CD34 항체에 대한 면역화학적반응에서는 침샘 종양 에서 감별진단이 필요한 여러 비혈구림프종양에서 면역화학 적반응이 나타난다. 이번 증례처럼 침샘에서 발생한 고립성 섬유종의 경우, 다형선종, 섬유조직구증, 혈관주위세포종 등 의 침샘 종양과의 감별이 중요하다.

다형선종은 침샘에서 가장 흔하게 발생하는 종양이며, 피 막 침윤 소견을 보이며, 내피구조물은 관 모양의 구조물을 형 성한다. 그리고, S-100을 표현하지 않는데 이는 근육상피세 포에서 기원하지 않음을 알 수 있다. 섬유조직구증은 일반적 으로는 CD34 항원에 음성으로 나타난다. 하지만 피하섬유조 직구증(피부섬유종)의 경우는 $18 \%$ 이상에서 CD34 항원에 양 성반응을 보인다. 이러한 경우에서는 조직의 형태로 감별진 단을 하는데, 고립성 섬유종은 많은 세포충실성과 조밀한 아 교질의 양상을 보이지만, 피부섬유종의 경우는 이런 양상을 보이지 않는다. 혈관주위 세포종과 고립성 섬유종의 감별은 서로 비슷한 점이 많아 어렵다. 따라서 앞의 두 종양을 진단 할 때는 주의가 필요하다. 혈관주위 세포종의 경우는, 구형, 타원형의 핵을 가진 세포로 구성되어 있으며, 저분화된 세포 로 구성된 얇은 벽의 혈관통로로 구성되어 있다. 반면에, 고 립성 섬유종은 방추세포들로 주로 구성되어 있다. 또한, 혈관 주위세포종은 고립성 섬유종보다 더 광범위한 혈관 양상을 보인다.

고립성 섬유종의 치료는 종양을 완전히 절제하는 것이다. 고립성 섬유종은 혈관이 풍부한 종양이므로 절제 시, 출혈을 항상 염두 해야 하며, 출혈이 심할 것이라 생각이 되면 수술 전, 혈관색전술을 고려해야 한다. 불완전 절제를 할 경우, 재 발 및 악성의 가능성이 높아지게 되므로 가능하면 완전 절제 를 하고 방사선치료를 병행하여 재발을 줄일 수 있다. 전신 항 암요법에 대해서는 아직 논란이 있다. ${ }^{4}$ 수술적 절제 후 6년 후까지 재발이 보고되었다고 알려져 있어, 장기간 추적관찰 이 필요할 것으로 생각된다.9)

두경부에 발생한 고립성 섬유종은 천천히 자라고 대부분 은 양성이지만 악성의 가능성이 있는 종양이다. 본 증례처럼 이하선에 생긴 고립성 섬유종의 경우 처음 내원했을 때는 특 별한 증상 없는 양성종양으로 확인되었으나, 이후 서서히 자 라면서 안면마비증상을 일으키고, 인근 림프절로 전이되었고, 최종적으로 악성으로 진단되었다. 따라서 이하선의 고립성 섬
유종이 의심될 경우, 수술적으로 완전 절제술을 시행하며, 원 격전이에 대한 추가검사도 시행해야 할 것이며, 전이가 확인 될 경우 방사선치료를 고려하는 등 적극적인 치료가 필요할 것으로 생각된다. 이후 재발 여부 확인을 위한 장기적인 추적 관찰도 필요하다.

안면신경마비를 유발하고 인근 림프절로 전이된 이하선의 고립성 육아종은 거의 보고되지 않은 드문 증례이기 때문에, 이번 증례를 통해 이하선의 고립성 섬유종의 적절한 치료 방 향을 설정하는 데 도움이 될 수 있을 것이다.

\section{REFERENCES}

1) Klemperer P, Coleman BR. Primary neoplasms of the pleura. A report of five cases. Am J Ind Med 1992;22(1):1-31.

2) Chan JK. Solitary fibrous tumour--everywhere, and a diagnosis in vogue. Histopathology 1997;31(6):568-76.

3) Daigeler A, Lehnhardt M, Langer S, Steinstraesser L, Steinau HU, Mentzel T, et al. Clinicopathological findings in a case series of extrathoracic solitary fibrous tumors of soft tissues. BMC Surg 2006;6:10.

4) Zuniga MG, Orr BA, Chang SS, Tufano RP. Suboccipital malignant solitary fibrous tumor: report of a case. Ear Nose Throat J 2012;91(2): E25-7.

5) Ahn TJ, Bae WY, Kim SJ, Kang MJ. Solitary fibrous tumor in nasal cavity: surgical treatment after angiographic embolization. Korean J Otorhinolaryngol-Head Neck Surg 2009;52(3):258-61.

6) Kim SH, Kim HJ, Park JY, Koo BS. Solitary fibrous tumor of the suboccipital area. Korean J Otorhinolaryngol-Head Neck Surg 2012;55(9):599-602.

7) Ganly I, Patel SG, Stambuk HE, Coleman M, Ghossein R, Carlson D, et al. Solitary fibrous tumors of the head and neck: a clinicopathologic and radiologic review. Arch Otolaryngol Head Neck Surg 2006;132 (5):517-25.

8) Gold JS, Antonescu CR, Hajdu C, Ferrone CR, Hussain M, Lewis $\mathrm{JJ}$, et al. Clinicopathologic correlates of solitary fibrous tumors. Cancer 2002;94(4):1057-68.

9) Cox DP, Daniels T, Jordan RC. Solitary fibrous tumor of the head and neck. Oral Surg Oral Med Oral Pathol Oral Radiol Endod 2010; 110(1):79-84.

10) Gengler C, Guillou L. Solitary fibrous tumour and haemangiopericytoma: evolution of a concept. Histopathology 2006;48(1):63-74.

11) Kim HY, Lee SY, Kang SJ, Kim HJ. Solitary fibrous tumor of the orbit: a poorly-recognized orbital lesion. Acta Ophthalmol Scand 1999;77(6):704-8.

12) Ridder GJ, Kayser G, Teszler CB, Pfeiffer J. Solitary fibrous tumors in the head and neck: new insights and implications for diagnosis and treatment. Ann Otol Rhinol Laryngol 2007;116(4):265-70.

13) Kim HJ, Lee HK, Seo JJ, Kim HJ, Shin JH, Jeong AK, et al. MR imaging of solitary fibrous tumors in the head and neck. Korean J Radiol 2005;6(3):136-42.

14) Hanau CA, Miettinen M. Solitary fibrous tumor: histological and immunohistochemical spectrum of benign and malignant variants presenting at different sites. Hum Pathol 1995;26(4):440-9.

15) Mearini E, Cochetti G, Barillaro F, Fatigoni S, Roila F. Renal malignant solitary fibrous tumor with single lymph node involvement: report of unusual metastasis and review of the literature. Onco Targets Ther 2014;7:679-85. 